Building Societies in the Financial Services

Industry 

Barbara Casu • Andrew Gall

\section{Building Societies in the Financial Services Industry}


Barbara Casu

Faculty of Finance

Cass Business School-City University

London, United Kingdom
Andrew Gall

Building Societies Association

London, United Kingdom

ISBN 978-1-137-60207-7

DOI 10.1057/978-1-137-60208-4

ISBN 978-1-137-60208-4 (eBook)

Library of Congress Control Number: 2016942676

(C) The Editor(s) (if applicable) and The Author(s) 2016

The author(s) has/have asserted their right(s) to be identified as the author(s) of this work in accordance with the Copyright, Designs and Patents Act 1988.

This work is subject to copyright. All rights are solely and exclusively licensed by the Publisher, whether the whole or part of the material is concerned, specifically the rights of translation, reprinting, reuse of illustrations, recitation, broadcasting, reproduction on microfilms or in any other physical way, and transmission or information storage and retrieval, electronic adaptation, computer software, or by similar or dissimilar methodology now known or hereafter developed.

The use of general descriptive names, registered names, trademarks, service marks, etc. in this publication does not imply, even in the absence of a specific statement, that such names are exempt from the relevant protective laws and regulations and therefore free for general use. The publisher, the authors and the editors are safe to assume that the advice and information in this book are believed to be true and accurate at the date of publication. Neither the publisher nor the authors or the editors give a warranty, express or implied, with respect to the material contained herein or for any errors or omissions that may have been made.

Printed on acid-free paper

This Palgrave Macmillan imprint is published by Springer Nature The registered company is Macmillan Publishers Ltd. London 


\section{FOREWORD}

Building societies and, indeed, the mutual concept itself were written off by many in the late 1990s. Those societies that saw themselves as innovative, risk-taking, and entrepreneurial had proudly cast away what they saw as the constraints of their mutual status. By 2000, they were ready to take their full and rightful role in the new, free, globalised financial markets that had been created by new technology and regulatory reform over the previous two decades.

A decade later, the ambition, excitement, and sense of self-belief among those who led this change had disappeared. By 2009, not a single one of the ten building societies that had turned themselves into banks retained their individual existence, and a number had been rescued by the taxpayer. In contrast, most of those societies that remained mutual, and fought to reinvent and enhance the meaning of mutuality, survived the financial crisis, and came out of it stronger. One of the most remarkable statistics in this welcome new book by Barbara Casu and Andrew Gall is that between 2011 and 2014, mutual building societies accounted for $90 \%$ of net new mortgage lending.

The history of this period is fascinating, and Casu and Gall provide a range of insights. The wealth of data in this book means it is set to become a standard statistical text on developments in this area. However, the authors go further, with helpful interpretations and analysis of market developments, financial performance, and customer views. The impact of regulatory change is not ignored; indeed, it is explained in some detail. It is interesting to reflect that, to some extent, the country chose to go down a route that led to such ruin. 
Vince Cable, Liberal Democrat Business Secretary in the 2010-2015 coalition government, said that the demutualisations had been "one of the great acts of economic vandalism in modern times." That statement deserves sustained reflection by policymakers and those who drive market behaviour. The huge and costly experiment to determine whether mutual or stock-based ownership models are best designed to provide customers with basic financial products has been comprehensively answered in mutuals' favour in recent years. Those wanting to understand "how" and "why" should spend a few hours with "Building Societies in the Financial Services Industry."

Adrian Coles Director General, The Building Societies Association, 1993-2013 


\section{Preface}

The UK financial services industry has been severely impacted by the financial crisis of 2007-2008, which resulted in UK banks suffering big losses. The financial turmoil resulted in significant government intervention in the sector. State aid was then followed by wide-ranging regulatory reforms, aimed at making the financial industry more resilient to shocks, by limiting risk-taking and improving bank conduct. As a consequence, the industry is undergoing a period of deep transformation, which affects all industry participants.

The implications of the global financial crisis on the banking sector have been widely analysed, less so the consequences on other financial intermediaries. Not all types of financial institutions were affected in the same way by the crisis.

Although the building society sector was not immune to the effects of the global financial crisis, on average, it managed to overcome it in better health than the banking industry.

An analysis of the key characteristics of the UK building society sector is therefore interesting to understand how different types of financial institutions have evolved during the deregulation era of the 1990s, when activity restrictions were abolished and banks and building societies started competing in the mortgage and savings markets, and how this affected the range of activities undertaken in the run-up to the financial crisis.

Building societies are mutual organisations, owned by their customers, or members. Although technically they are not "banks" and do not offer the full range of banking services, as mutuals they are a subset of stakeholder-based financial institutions. Understanding the key features of 
their business models and analysing their strengths and weaknesses compared to banks are particularly interesting as policymakers are seeking to foster a more diverse financial sector. In recent years, building societies have enjoyed political support as the importance of mutuals within a more diverse financial sector has been highlighted by policymakers and regulators. This support is also recognised by customers, as indicated by the high levels of satisfaction and trust.

This book aims to describe the performance of UK building societies since the large-scale demutualisation process ended in the year 2000 . Chapter 1 offers an overview of the UK financial services industry and reviews the impact of the global financial crisis on UK banking. It also provides an analysis of the changing structure of the UK banking sector: from increased concentration, which resulted in the sector being dominated by few, very large, banking groups to the recent entrance of new "challenger" banks. The entrance of new banks, with new banking licences being issued for the first time in a century, is likely to increase competition, particularly in the retail banking sector. This increased competition, in addition to the effect of regulatory reforms, as well as far-reaching technological innovations, presents new challenges for the building society sector. Chapter 2 presents a brief summary of UK building societies' 250 years of history. We focus in particular on the demutualisation process that saw the largest building societies becoming banks. We then assess the impact of the financial crisis on the sector; we analyse the consolidation process that took place as larger and more sound building societies took over troubled ones. Chapter 3 reviews the legal and regulatory framework with respect to building societies' permissible activities and discusses recent developments. In addition, we consider the strengths and weaknesses of the building society model, with a particular focus on capital and governance. Chapter 4 presents an analysis of the key issues faced by building societies in today's financial markets. We discuss the key changes in the structure of the industry and how these have impacted on margins and profitability and have resulted in restructuring and consolidation in the sector. Finally, Chapter 5 presents an empirical analysis of the comparative performance of UK banks and building societies since the year 2000. When comparing societies against standard bank performance metrics, we have been careful in the interpretation of the results not to provide a biased view of the sector's performance. We believe this analysis to be informative to demonstrate the differences between types of organisations competing in 
the market and therefore helpful to policymakers weighing up the future shape of the banking sector.

Barbara Casu

Faculty of Finance, Cass Business School, City University London, UK

Andrew Gall Building Societies Association, London, UK 



\section{ACKNOWLEDGEMENTS}

This text could have never been completed without the help and support of a number of individuals. First and foremost, the authors must acknowledge the financial support of the Building Societies Association (BSA). The results of the empirical analysis presented in Chapter 5 are part of a Report commissioned by the BSA to the Centre for Banking Research at Cass Business School. The Report titled An analysis of the comparative performance of $U K$ banks and building societies was presented at the BSA London offices on Wednesday, 9 September 2015. The authors have greatly benefited from discussion and feedback from participants at the event. In compiling this book, we would also like to acknowledge the comments and discussion provided by Rym Ayadi, Laura Chiaramonte, Adrian Coles, Claudia Girardone, David Llewellyn, Donal McKillop, Philip Molyneux, Barry Quinn, Anna Sarkisyan, John O.S. Wilson, Robin Fieth, Chris Lawrenson, Jeremy Palmer, and Simon Rex. We also want to acknowledge the support of our home institutions, Cass Business School, City University London, and the BSA.

Finally, we wish to thank our families for their encouragement and support. Barbara Casu thanks her husband for his help with various aspects of this book and her children for their patience. Andrew Gall thanks his wife for her constant support. 



\section{Acronyms and Abbreviations}

AGM Annual General Meeting

APPG All-Party Parliamentary Group

ATl Additional Tier 1

ATM Automated Teller Machine

BBA British Bankers' Association

BCBS Basel Committee on Banking Supervision

BOE Bank of England

BSA Building Societies Association

C/I Cost-to-Income

CCDS Core Capital Deferred Shares

CET1 Common Equity Tier 1

CRR Capital Requirements Regulation

DBS Dunfermline Building Society

DTI Debt-to-Income

ECB European Central Bank

EU European Union

FCA Financial Conduct Authority

FLS Funding for Lending Scheme

FOS Financial Ombudsman Service

FPC Financial Policy Committee

FSA Financial Services Authority

FSCS Financial Services Compensation Scheme

HBOS Halifax Bank of Scotland

ICB Independent Commission on Banking

IFS Institute for Fiscal Studies

IT Information Technology

KRBS Kent Reliance Building Society 
LIBOR London Interbank Offered Rate

LTI Loan-to-Income

LTV Loan-to-Value

M\&S Marks and Spencer

MBBGs Major British Banking Groups

MPC Monetary Policy Committee

NAB National Australia Bank

NIM Net Interest Margin

NS\&I National Savings \& Investments

OBS Off-Balance Sheet

ONS Office for National Statistics

PIBS Permanent Interest Bearing Shares

plc Public Limited Company

PPDS Profit Participating Deferred Shares

PPI Payment Protection Insurance

PRA Prudential Regulatory Authority

RBS Royal Bank of Scotland

ROA Return on Assets

ROE Return on Equity

SFTs Securities Financing Transactions

TBTF Too-Big-To-Fail

UK United Kingdom

UKAR UK Asset Resolution

UKFI UK Financial Investments Ltd

US United States of America

YoY Year on Year 


\section{Contents}

1 Financial Services and the UK Economy

2 A Brief History of Building Societies

3 Legislation, Regulation, and Governance of Building Societies

4 Financial Structure of the Building Society Sector

5 The Performance of Building Societies: A Comparative Analysis

Index 



\section{List of Figures}

Fig. 1.1 GDP growth (\%) Year on Year 3

Fig. 1.2 UK average house prices 4

Fig. 1.3 Number of banks and building societies (2000-2013) 9

Fig. 1.4 Concentration ratio (CR5) 10

Fig. 1.5 Total employment in banks and building societies (as \% of total employment) 13

Fig. 1.6 Branches and ATMs (1990-2013) 14

Fig. 1.7 High street banks' share of new lending approvals (\%) 14

Fig. 2.1 Historic mortgage market shares (\%) 32

Fig. 2.2 Corporate diversity index for the UK mortgage market 36

$\begin{array}{lll}\text { Fig. 3.1 Building society balance sheet structure } & 49\end{array}$

Fig. 4.1 Building societies' margins profitability and expenses 63

Fig. 4.2 UK net mortgage lending, $£$ m 65

Fig. 4.3 Changes in UK household savings balances 67

Fig. 4.4 Financial Ombudsman Complaint Statistics 71

Fig. 5.1 Asset growth (\%) 82

Fig. 5.2 Asset growth-MBBGs and Peer Groups 83

Fig. 5.3 Loan growth (\%) 84

Fig. 5.4 Loan growth-MBBGs and Peer Groups. 85

Fig. 5.5 Return on equity 86

Fig. 5.6 Return on equity—MBBGs and Peer Groups 86

$\begin{array}{lll}\text { Fig. 5.7 Return on assets } & 87\end{array}$

$\begin{array}{lll}\text { Fig. 5.8 Return on assets-MBBGs and Peer Groups } & 87\end{array}$

$\begin{array}{lll}\text { Fig. } 5.9 \text { Volatility of return on equity } & 88\end{array}$

$\begin{array}{lll}\text { Fig. } 5.10 & \text { Volatility of return on assets } & 88\end{array}$

Fig. 5.11 Net interest margin $\quad 89$

Fig. 5.12 Volatility of net interest margin 90 
xviii LIST OF FIGURES

Fig. 5.13 Net interest margin-MBBGs and Peer Groups 91

Fig. 5.14 Cost to income ratio 91

Fig. 5.15 Cost to income ratio-MBBGs and Peer Groups 92

Fig. 5.16 Leverage Ratio 93

Fig. 5.17 Leverage ratio-MBBGs and Peer Groups 93

Fig. 5.18 Tier l common capital ratio (CETl) 94

Fig. 5.19 z-score $\quad 95$

Fig. 5.20 z-score-MBBGs and Peer Groups $\quad 95$

Fig. 5.21 Volatility of z-score 96 


\section{List OF TABLES}

Table 1.1 Economic Indicators $\quad 5$

Table 1.2 Total Staff-Banks and Building Societies (2000-2012) 12

Table 2.1 Building society operational statistics 25

Table 2.2 Demutualisation of the UK building society sector (1989-2000) 27

Table 2.3 Transfers of engagements: 2008-2015 38

Table 2.4 Size and rank of Merged Building Societies (2008-2015) 41

Table 4.1 Customer satisfaction survey-Average (Q2:2014-Q4: 2015) 69

Table 4.2 Conduct fines levied by UK conduct regulators (2010-2015) 72

Table 5.1 Descriptive statistics-banks and building societies (averages in $£$ million) 